\title{
Major determinants of fruit set and yield fluctuation in coconut (Cocos nucifera L.)
}

\author{
C.S. Ranasinghe*, L.R.S. Silva and R.D.N. Premasiri \\ Plant Physiology Division, Coconut Research Institute, Bandirippuwa Estate, Lunuwila.
}

\begin{abstract}
The final yield of coconut (Cocos nucifera L.) is determined by early fruit set. Thus understanding the factors controlling fruit set including climate change is of importance for assessing the yield and its accurate prediction. This study assessed the survival pattern of female flowers produced in different months of the year, the effects of climate factors during early phase of flowering and the competition for assimilates from previously formed fruits on the fruit set of newly opening inflorescences in a $25-26$ year-old coconut plantation in the Intermediate Zone $\left(\mathrm{IL}_{1 \mathrm{a}}\right)$ of Sri Lanka over a period of three years. The rate of fruit survival since the onset of flowering to maturity varied with the month of inflorescence opening. Abortion of fruits after three months from inflorescence opening was negligible. The optimum $\left(\mathrm{T}_{\text {opt-in vitro }}\right)$ and maximum $\left(\mathrm{T}_{\text {max-in vitro }}\right)$ temperatures for in vitro pollen germination were $28^{\circ} \mathrm{C}$ and $39.7{ }^{\circ} \mathrm{C}$, respectively. The fruit set of an inflorescence/s opened in a given month (number of set fruits palm ${ }^{-1}$ month $^{-1}$ ) was negatively correlated with the total reproductive dry matter requirement of the palm (TDMR) of the month of inflorescence/s opening (first month), and the number of high temperature days $\left(\mathrm{T}_{\max } \geq 33^{\circ} \mathrm{C}\right)$ during the first three months of inflorescence opening, whilst it was positively correlated with the number of female flowers produced in the inflorescence. There was a highly significant correlation between the monthly fruit set (at three month stage) and the corresponding harvested fruit yield palm $^{-1}$ month $^{-1}$. The lag period between flowering (opening of the female phase) and fruit maturing was eleven months.
\end{abstract}

Keywords: Climate change, coconut, dry matter requirement, fruit set, high temperature, pollination, respiration.

\section{INTRODUCTION}

Fruit set during early months after inflorescence opening is an important yield determinant in coconut (Cocos nucifera L.) (Peiris et al., 1995). Initial fruit set can be low due to unfavourable environmental factors viz., high temperature, low light conditions or water stress in perennial crops such as coconut (Kasturi Bai et al., 2003; Thomas et al., 2012), oil palm (Legros et al., 2009) and other fruit crops (Wubs et al., 2009b). Under non-stress conditions, the number of fruits set in a newly opening inflorescence can also be low due to low production of female flowers or high competition for assimilates from previously formed fruits (strong sinks) (Henson, 2007; Wubs et al., 2009a). Since detailed quantitative information on the effect of the above factors on fruit set in coconut is lacking, it is important to investigate and quantify the factors governing variations of fruit set in coconut for accurate prediction of coconut yield, assessing possible effects of climate change and selecting coconut cultivars that can adapt to adverse effects of climate change.

The apical meristem of coconut forms phytomeres in linear and regular succession, consisting of a leaf, an internode and an inflorescence. This branched inflorescence carries both male and female flowers on spikelets, the former at the upper end and the latter at the base of each spikelet. Thus, coconut shows an indeterminate growth pattern, producing an inflorescence at each leaf axil at intervals varying from 25 to 30 days, depending on the environmental conditions and the age of the palm (Liyanage, 1950). At any time a healthy coconut palm carries $12-14$ inflorescences (bunches) with varying numbers of fruits at different developmental stages. Although the male and female flowers are located close together on each inflorescence, the commercially grown Sri Lanka Tall (SLT) coconut is primarily out-breeding as the pollen is shed before the female flowers become receptive. Mature coconut bunches are harvested monthly or bimonthly and the crop shows variation in yield between months and years. 
High temperatures badly affect crop productivity, specially when temperature extremes coincide with drought at critical stages of plant reproductive development (Zinn et al., 2010). A high number of flower and fruit abortions under high temperature is often observed in coconut plantations in the Intermediate and Dry Zones of Sri Lanka even under irrigation (Nainanayake et al., 2008). This could be attributed to the exposure of the pollination phase to temperatures as high as $34-36{ }^{\circ} \mathrm{C}$, which is well above the optimum temperature for pollen germination $\left(25-30{ }^{\circ} \mathrm{C}\right)$ in many field-grown crops (Burke et al., 2004). Furthermore, reduced fruit set of coconut in drought-prone areas can be attributed to lower quality of pollen and/or female flowers due to the exposure of flowers to drought stress during their final stages of development (Ranasinghe et al., 2014). Reproductive organs are more vulnerable to heat stress than vegetative organs, and the number of set fruits can be reduced by timing of exposure (sensitive period) as well as duration of exposure to high temperature (Peiris $\&$ Thattil, 1997). A significant relationship between the number of days of exposure to high temperature and the percentage of fruit set has been reported in many greenhouse and field-grown crops (Vara Prasad et al., 2000; Wubs et al., 2009b). Abortion of female flowers or young fruits is common in coconut even when they are grown under favourable climatic conditions (Navarro et al., 2008). Within plant competition between organs is based on the source-sink relationships, representing the supply and demand of assimilates. The cause of seasonal variation in net primary productivity of coconut was due to the differences in fruit development and not due to the gross assimilate production under tropical climatic conditions (Navarro et al., 2008). Therefore, it could be assumed that the variation in sink strength of a palm is more critical than the variation in source strength in determining the variation in fruit set. Sink strength of a palm is the total dry matter requirement for potential growth and respiration (Henson, 2007). The growth rate and respiration of vegetative organs (leaf and stem) of coconut did not vary with the season or growth condition (Mialet-Serra et al., 2008; Navarro et al., 2008), except under extremely unfavourable soil conditions (Ranasinghe et al., 2011). Therefore, the sink strength of vegetative organs can be assumed constant; hence the driving force of seasonal variation in fruit set could be associated with the sink strength of reproductive organs [assimilate requirement of reproductive organs (developing fruits in all bunches)]. The present study is aimed at assessing the survival pattern of female flowers produced in different months, the response of in vitro pollen germination to temperature and the relationship between female flower production, climate factors and competition for assimilates and fruit set.

\section{METHODS AND MATERIALS}

Two experiments were conducted. The first was to determine the monthly variations in female flower production, fruit set and survival, assimilate demand of reproductive organs (competition) and the response of in vitro pollen germination to temperature. The second was to study the potential assimilate demand of a single fruit (for growth and respiration) at 14 different growth stages. The data of the second experiment were used to estimate the total assimilate demand of a palm studied in the first experiment.

\section{Experiment 1}

The experiment was conducted in two locations in coconut plantations covering more than 50 ha in Wellawa, Kurunegala situated in the North-West of Sri Lanka (lat $7^{\circ} 34^{\prime} \mathrm{N}$, long $80^{\circ} 23^{\prime} \mathrm{E}$ ). The selected plantations are in the low country intermediate $\left(\mathrm{IL}_{\mathrm{la}}\right)$ agro-ecological region representing the major coconut growing area and soil types in Sri Lanka. Generally, these coconut growing areas are prone to drought during January - March and July - September (Peiris et al., 2008). Eight coconut palms [Sri Lanka Tall $\times$ Sri Lanka Tall $($ SLT $\times$ SLT, commercial variety typica)] were selected randomly from two sites covering about 10 ha each (altogether 16 palms). The plantations were of uniform age (25 - 26 years) and density, and subjected to cultural practices recommended by the Coconut Research Institute of Sri Lanka (CRISL). The data were collected monthly between January 2009 - December 2011 (unless otherwise stated, the data reported in this paper are from experiment 1 ).

\section{Experiment 2}

Forty healthy coconut palms (SLT x SLT, variety typica) selected from the Walpita Research Station [Western Province, Wet Zone (lat $7^{\circ} 15^{\prime} \mathrm{N}$, long $80^{\circ} 2^{\prime}$ E)] and the Makandura Research Station [Western Province, Wet Intermediate Zone (lat $7^{\circ} 19^{\prime} \mathrm{N}$, long $79^{\circ} 58^{\prime} \mathrm{E}$ )] of the CRISL were used to estimate the dry matter requirement at different growth stages from pollinated flower to mature fruit. Both plantations were also of similar age and density as the plantation used in experiment 1 $(25-26 \mathrm{yrs})$ and also managed in the same manner.

\section{Observations on female flower production and fruit survival pattern}

The palms were observed every month for the survival of female flowers and fruits in each inflorescence. The data were used to develop survival curves for inflorescences opened during different months. Reproductive organs 
that aborted were either flowers or young fruits and this study took into account both stages. The survival analysis produces a curve indicating the number of fruits surviving at a given time after inflorescence opening (Wubs et al., 2011). Further, the monthly mean data were used to test the relationship between monthly female flower production and their fruit set.

\section{Fruit set}

The number of set fruits was determined for each inflorescence when the number of surviving fruits reached a constant value and the aborted fruits were negligible with time in the survival curve. Although coconut palms generally produce one inflorescence per month, there were one or two occasions between March and September, where the palms produced two inflorescences per month. In such months, the total number of female flowers produced and surviving fruits in both inflorescences were considered as the respective month's flower production and fruit set.

\section{Determination of total dry matter requirement for growth and respiration of developing fruits of a palm}

The total dry matter requirement for potential growth and respiration of developing fruits of a palm was quantified through the following three steps.

Step 1: Dry matter requirement for potential growth of individual fruits of different developmental stages (from experiment 2): The dry matter requirement for potential growth, from pollinated flower to mature fruit, was obtained by non-destructive measurements on 'potentially growing' fruits. Conditions for potential fruit growth were created by tagging the fruits in each inflorescence and recording their growth rate under 'resource unlimited' conditions. To accomplish this condition, four fruits on the newly pollinated youngest inflorescence (first), two fruits each on the second and third inflorescences and one fruit each on the other developing inflorescences were retained and all the other developing flowers and fruits were removed (since some fruits of the first three inflorescences are prone to abort, more than one fruit was retained on the three youngest inflorescences). The developmental stages were approximately equally spaced in time. Data collection was done in May and June 2009 under highly favourable soil ( $\mathrm{S}_{2}$ land suitability class) (Somasiri et al.,1994) and environmental conditions (no soil moisture stress, favourable temperature and solar radiation intensity) (Figure 1a, 1b). The fruits were assumed to grow with minimum competition under optimum environmental conditions to attain the potential size of each stage. Vertical circumference of the tagged fruits was measured at time $t_{1}$ (May 2009) and after one month at time $t_{2}$ (June 2009), and the fruit dry matter content at $t_{1}$ and $t_{2}$ was estimated non-destructively by a fitted empirical relationship developed for SLT x SLT variety (Ranasinghe, 2008). The potential dry matter increase of fruit month ${ }^{-1}$ (potential growth rate, PGR) for each developing stage was calculated by the difference in the estimated dry weight of fruits between months $\left(t_{2}-t_{1}\right)$.

Step 2: Dry matter requirement for respiration of individual fruits of different developmental stages (from experiment 2): The dry matter requirement for respiration of fruits of each developmental stage was estimated according to Navarro et al. (2008) and Ranasinghe and Thimothias (2012).

$$
\begin{aligned}
& R=R_{g}+R_{m}=\alpha N P P+0.4 \beta B \\
& R \text { - Respiration of developing fruits }\left(\mathrm{g} \mathrm{C} \mathrm{m}^{-2} \text { day }^{-1}\right) \text {, } \\
& \alpha \text { - Growth respiration coefficient }\left(\mathrm{g} \mathrm{C} \mathrm{g}_{\mathrm{DM}}{ }^{-1}\right) \\
& \text { NPP - Net primary production of fruits (potential growth }
\end{aligned}
$$

(Assumption: $\alpha$ and $\beta$ do not vary with the growth stage of fruits; limitations of this assumption are explained in the discussion section)

The total dry matter requirement of a fruit was calculated as the sum of dry matter requirement for potential growth (PGR) and respiration (R) for each stage. This information was used to estimate the monthly total dry matter requirement of fruits of the palms used in experiment 1 .

Step 3: Monthly variation in total dry matter requirement of palms: The total dry matter requirement of each inflorescence of a palm (experiment 1) was calculated by multiplying the requirement of individual fruits (obtained through experiment 2) by the actual number of fruits remaining in an inflorescence every month. The total dry matter requirement by reproductive organs of a palm month ${ }^{-1}$ (TDMR) was estimated by summing up the requirements of all inflorescences (bunches) on a palm in a given month. The relationship between the monthly TDMR and the monthly fruit set of inflorescence/s opened during the same month was tested. 


\section{Determination of optimum $\left(\mathrm{T}_{\text {opt-in vitro }}\right)$ and maximum ( $\left.\mathrm{T}_{\text {max-in vitro }}\right)$ temperatures for in vitro- pollen germination}

The spikelets with mature (ready to open) male flowers were sampled from the middle of the inflorescence within three to eight days after opening of the spathe (cover of the inflorescence) between 9.00 - $10.00 \mathrm{am}$ (Liyanage, 1950) in May and June 2009. The collected spikelets were immediately put into labelled, clear polythene bags, placed on ice, brought to the laboratory and kept under refrigerated conditions until used for analysis. To minimise the effect of variation between the trees on temperature response of pollen germination, male flowers sampled from the middle of the spikelets of all 16 palms were pooled to one sample before using them for pollen germination test. Pollen was collected by slicing the anthers using a needle.

Pollen was dusted into microfuge tubes containing $0.5 \mathrm{~mL}$ of germination solution $\left(100 \mathrm{~g} \mathrm{~L}^{-1}\right.$ sucrose, $2 \mathrm{mM}$ boric acid, $2 \mathrm{mM}$ calcium nitrate, $2 \mathrm{mM}$ magnesium sulfate and $1 \mathrm{mM}$ potassium nitrate). Pollen from three male flowers was always introduced into one tube and the tubes were incubated at pre-determined temperatures from $20-38{ }^{\circ} \mathrm{C}$ at $2{ }^{\circ} \mathrm{C}$ intervals. Incubators were maintained at treatment temperatures; the temperature of the growth medium was not measured and assumed to be equal to the set temperature. Time course of in vitro pollen germination at room temperature has revealed that coconut pollen germination was apparent within the first $30 \mathrm{~min}$ of incubation on the media and constant after 16 hrs (Ranasinghe et al., 2010). Therefore, the number of germinated and non germinated pollen at each temperature regime was recorded after $24 \mathrm{hrs}$. A drop of germination solution was added on to a microscope slide and mounted a cover slip. Counts were made under a light microscope $(10 \times 10)$ (Olympus Optical Co., Tokyo, Japan). A pollen grain was considered germinated if it produced a tube longer than the diameter of the grain (Kakani et al., 2002). Pollen germination percentage ( $\%$ PG) was determined by dividing the number of germinated pollen grains per field of view, by the total number of pollen grains per field of view and expressed as percentage. After $24 \mathrm{hrs}$ of incubation, 15 microscopic fields prepared from five microfuge tubes of pollen ( 3 slides were prepared from one tube) were used to analyse the percentage pollen germination $(\% \mathrm{PG})$ at each temperature regime. The experiment was repeated three times and the data from all three experiments were used for the analysis. The maximum pollen germination recorded after $24 \mathrm{hrs}$ of incubation at each temperature was analysed using linear and non-linear regression techniques commonly used to quantify pollen parameter response to temperature (Kakani et al., 2002; 2005; Reddy \& Kakani, 2007). Curve estimation and non-linear regression procedures in SPSS were used to estimate the parameters of the fitted models. The bilinear equation (equation 1) was used to estimate $\mathrm{T}_{\text {opt-in vitro }}$ (optimum temperature where maximum pollen germination occurred) and $\mathrm{T}_{\text {max-in vitro }}$ (maximum temperature above which pollen grains did not germinate) for pollen germination.

$\% \mathrm{PG}=\mathrm{a}+\left[\mathrm{b}_{1}\left(\mathrm{t}-\mathrm{T}_{\text {opt-invitro }}\right)\right]+\left[\mathrm{b}_{2}\left(\mathrm{ABS}\left(\mathrm{t}-\mathrm{T}_{\text {opt-invitro }}\right)\right)\right]$

\% PG: pollen germination (\%); $a, b_{1}$ and $b_{2}$ : equation constants, t: the various temperatures at which pollen germination was carried out and $\mathrm{T}_{\text {opt-in vitro }}$ : the optimum temperature for pollen germination.

Value of $\mathrm{T}_{\text {max-in vitro }}$ (maximum temperature at which the pollen germination is zero) was estimated using equation 2 from the constants in equation 1.

$\mathrm{T}_{\text {max-invitro }}=\frac{\left[\mathrm{a}-\mathrm{T}_{\text {opt-invitro }}\left(\mathrm{b}_{2}+\mathrm{b}_{1}\right)\right]}{\left(\mathrm{b}_{1}+\mathrm{b}_{2}\right)}$

\section{Climatic factors}

Maximum temperature (day) $\left(\mathrm{T}_{\max }\right)$, minimum temperature (night) $\left(\mathrm{T}_{\min }\right)$, solar radiation intensity and rainfall were considered as the main climate parameters that can influence fruit set and abortion. For many fruit crops, the critical temperature for fruit abortion was reported as $33{ }^{\circ} \mathrm{C}$ (Wubs et al., 2009b). Therefore, the number of days with high temperature $\left(\geq 33^{\circ} \mathrm{C}\right)$, monthly rainfall and solar radiation intensity during the first three months (most sensitive period) of inflorescence opening were related to monthly fruit set. To evaluate the effect of the intensity of drought on fruit set, the climatic water balance (CWB) was calculated as monthly rainfall minus potential evapotranspiration (Allen et al., 1998). Daily rainfall data collected at the Wellawa Meteorological Station ( $2 \mathrm{~km}$ from the experimental site) and daily solar radiation intensity and temperature data from the Kurunegala Meteorological Station $(5 \mathrm{~km}$ from the experimental site) were used.

\section{Relationship between fruit set, yield and the lag period}

Monthly fruit yield was the total number of fruits palm $^{-1}$ harvested in a calendar month. The harvesting 
frequency of experimental palms was monthly (precisely $30 \pm 3$ days). The relationship between the number of fruits harvested and the number of set fruits of the same inflorescence at three months after opening was tested.

\section{Data analysis}

The data were subjected to a generalised linear model (GLM) procedure to compare female flower production, fruit set, final fruit yield and total reproductive dry matter requirement (TDMR) of a palm month ${ }^{-1}$ between main factors (years and months) and the interactions. Regression analysis was used to assess the linear dependency of fruit set on TDMR, female flower production and climatic factors. Analyses were carried out using SAS software (SAS Institute, Version 6.0).

\section{RESULTS}

\section{Climatic parameters}

The monthly variations in climatic factors during experimental period are shown in Figures 1a and 1b.

Female flower production, fruit set and fruit survival in relation to inflorescence opening month

A significant difference $(\mathrm{p} \leq 0.05)$ in total female flower production among the years was recorded $(5359 \pm 1.24$, $4275 \pm 0.96$ and $6169 \pm 1.23$ flowers year ${ }^{-1}$ in 2009 , 2010 and 2011, respectively). The monthly mean flower production in $2011\left(33.3 \pm 1.23 \mathrm{month}^{-1}\right)$ was significantly higher and the monthly mean female flower production in $2010\left(22.4 \pm 0.96\right.$ month $\left.^{-1}\right)$ was significantly lower compared to the other years $\left(28.1 \pm 1.24\right.$ month $^{-1}$ in 2009). Irrespective of the year, the highest number of female flowers palm ${ }^{-1}$ was produced in May $(38.91 \pm 3.07)$ and it was significant compared to the other months except August $(33.04 \pm 2.09)$ (Figure 2). Significantly low

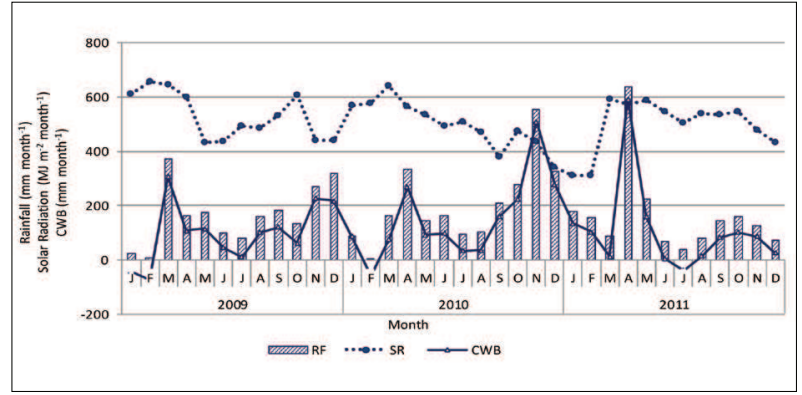

Figure 1a: Fluctuations in monthly rainfall (RF), climatic water balance (CWB) and solar radiation intensity (SR) over the experimental period

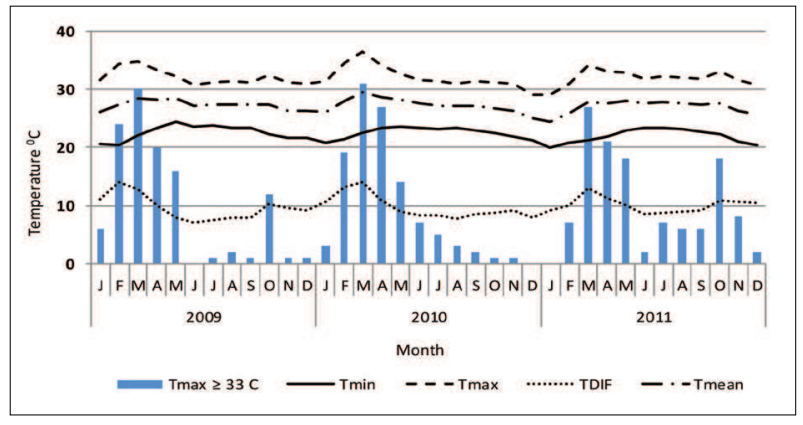

Figure 1b: Fluctuations in monthly maximum temperature $\left(\mathrm{T}_{\max }\right)$, minimum temperature $\left(\mathrm{T}_{\text {min }}\right)$, mean temperature $\left(\mathrm{T}_{\text {mean }}\right)$, difference between $\mathrm{T}_{\text {max }}$ and $\mathrm{T}_{\min }\left(\mathrm{T}_{\mathrm{Dif}}\right)$ and days with $\mathrm{T}_{\max }$ greater than $33^{\circ} \mathrm{C}$ over the experimental period

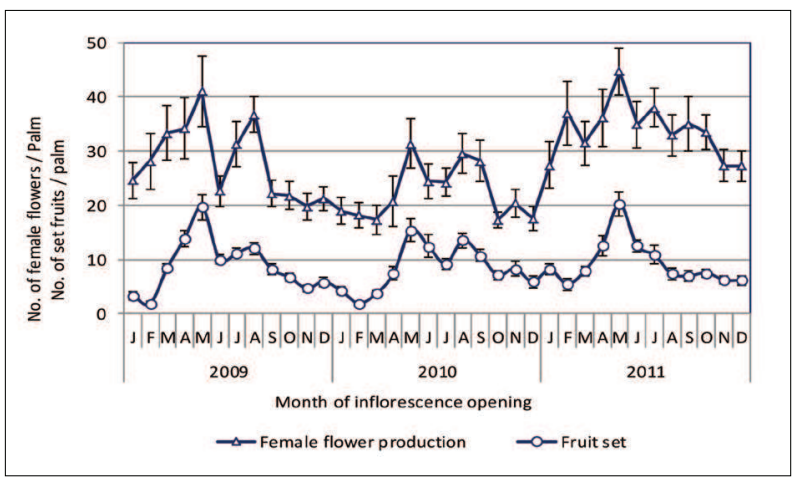

Figure 2: Patterns of female flower production and fruit set (FS at three month stage) of the inflorescences 'emerged' from January 2009 through December 2011. Error bars indicate standard error of monthly means.

numbers of female flowers were produced in November $(22.47 \pm 1.58)$ and December $(22.12 \pm 1.47)$ compared to April (30.21 \pm 3.10$)$, May (38.91 \pm 3.07$)$, July (31.15 \pm $2.15)$ and August $(33.04 \pm 2.09)$.

The survival pattern of fruits (from flowering to maturity) of the inflorescences opened from January to December during the experimental period showed differences between the months as shown in survival curves of contrasting months; February (lowest survival rate, Figure 3a) and May (highest survival rate, Figure $3 \mathrm{~b}$ ). There was an initial decrease in the survival of young fruits, but this leveled off after about 2-3 months. Irrespective of the month of inflorescence opening, the maximum flower or fruit abortion occurred during the first two months after opening of the inflorescence and fruit abortion was negligible after the third month. It was observed that in inflorescences opened during March and 
April, a notable fruit abortion occurred only in the first two months after opening of the inflorescence. The number of fruits surviving three months after inflorescence opening was significantly high $(\mathrm{p} \leq 0.05)$ in inflorescences opened in May $\left(18.7 \pm 1.27\right.$ fruits palm $\left.{ }^{-1}\right)$ compared to other months [3.6 (February) -11.7 (June) fruits palm ${ }^{-1}$ (Figure 2 ). The survival of fruits was lowest in inflorescences

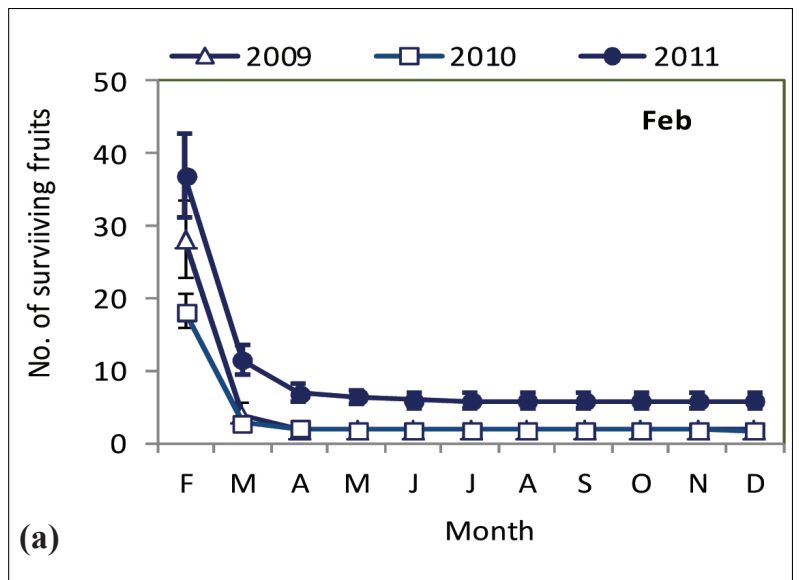

opened in January $\left(5.19 \pm 0.53\right.$ fruits palm $\left.{ }^{-1}\right)$ and February $\left(3.04 \pm 0.47\right.$ fruits palm $\left.{ }^{-1}\right)$.

There was a significant positive correlation between the number of female flowers produced in a given month and the number of fruits set on the same inflorescence after three months $\left(\mathrm{p}<0.001, R^{2}=0.44\right)$ (Figure $3 \mathrm{c}$ ).

Figure 3a,b: Number of female flowers or fruits surviving on inflorescence opened in February (Figure 3a) and May (Figure 3b) in 2009,2010 and 2011. Error bars indicate standard error of means.

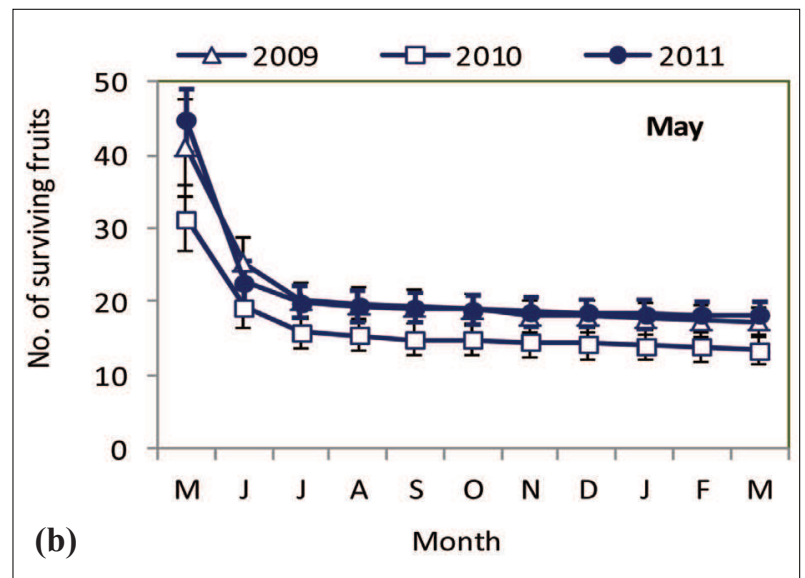

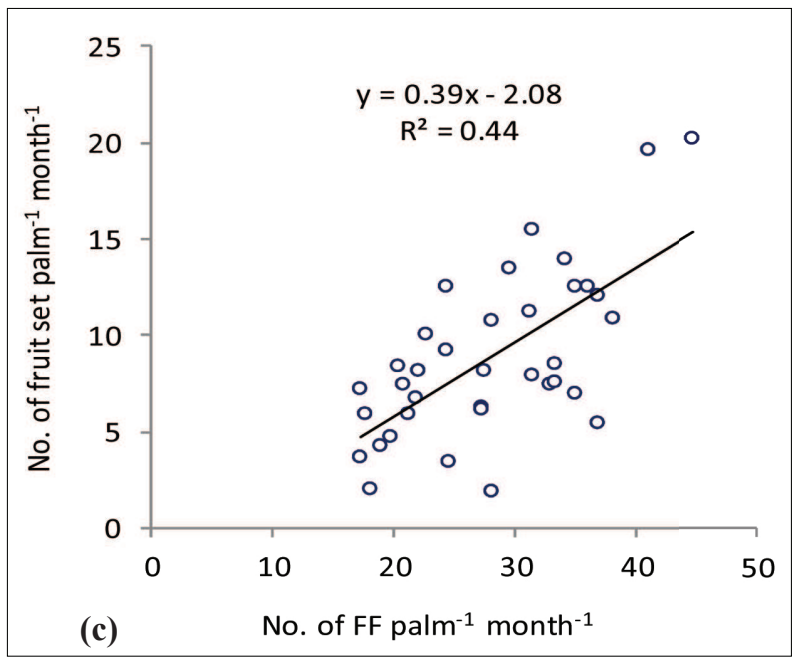

Figure 3c: Relationship between the number of female flowers produced palm ${ }^{-1}$ month $^{-1}$ and the number of fruits set on the same inflorescence after three months

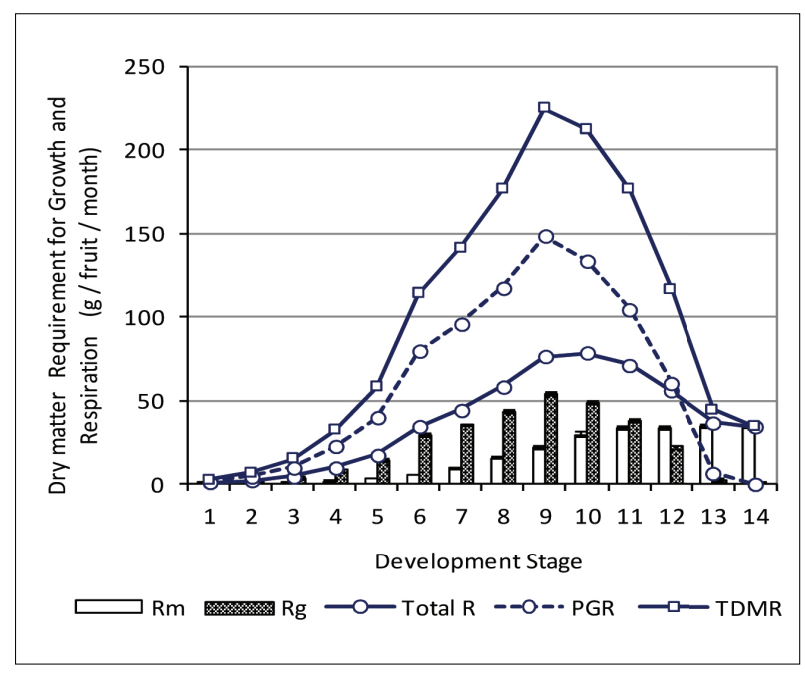

Figure 4: Dry matter requirement for growth (PGR), respiration [maintenance $\left(\mathrm{R}_{\mathrm{m}}\right)$, growth $\left(\mathrm{R}_{\mathrm{g}}\right)$ and total (total $\left.\mathrm{R}\right)$ ] and total of growth and respiration (TDMR) of developing fruits

Note: Development stage 1 refers to the fruit just after pollination and stage 14 refers to the most mature fruit (data from experiment 2). The developmental stages are approximately equally spaced in time; approximately $27-29$ days, thus there are 14 bunches present at a time on the palms. 
Inflorescences (female phase) opened from January to December in a particular year were harvested as mature fruit bunches from November of the same year to October of the following year (in the $11^{\text {th }}$ month after female flower opening).

Relationship between fruit setting and total dry matter requirement of reproductive organs (TDMR)

Dry matter requirement of an individual fruit for growth (PGR) increased with age from developmental stage one to nine (up to $150 \mathrm{~g}$ fruit ${ }^{-1}$ month $^{-1}$ ), and the rate of increase was the highest in developmental stages five to six $\left(39 \mathrm{~g} \mathrm{fruit}^{-1}\right.$ month $\left.^{-1}\right)$ (Figure 4). Dry matter requirement for growth respiration $\left(\mathrm{R}_{\mathrm{g}}\right)$ followed the same trend as PGR and the requirement for maintenance respiration $\left(\mathrm{R}_{\mathrm{m}}\right)$ increased with maturity up to the $11^{\text {th }}$ stage and remained constant (Figure 4). Consequently, the total dry matter requirement for respiration (total $\mathrm{R}$ for $\mathrm{R}_{\mathrm{g}}$ and $\mathrm{R}_{\mathrm{m}}$ ) of a fruit was the highest at ninth to tenth developmental stages and it was about $80 \mathrm{~g}$ fruit ${ }^{-1}$ month $^{-1}$. The total dry matter requirement for growth (PGR) and respiration (R) of a fruit was also the highest at $9^{\text {th }}-10^{\text {th }}$ stage and it was about $225 \mathrm{~g}$ fruit $^{-1}$ month $^{-1}$ (Figure 4).

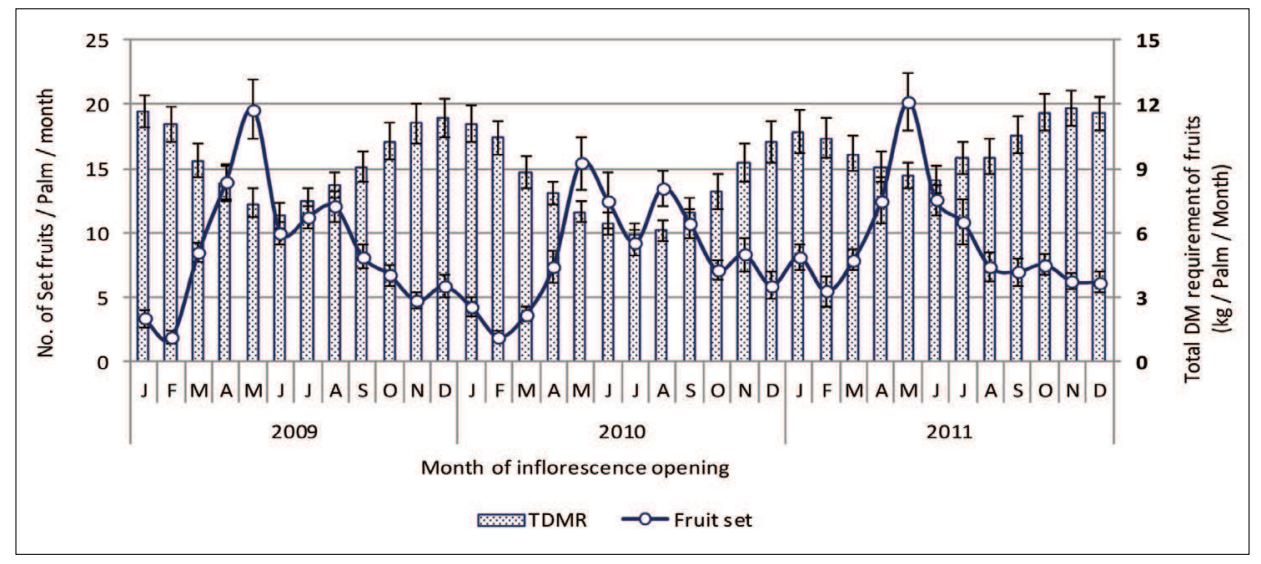

Figure 5a: Pattern of monthly total reproductive dry matter requirement (TDMR) and fruit set (FS) of the inflorescences opened in the same month from January 2009 through December 2011

Total dry matter requirement (TDMR) palm ${ }^{-1}$ differed between months and years (Figure 5a). The mean TDMR in $2011\left(10.2 \pm 0.23 \mathrm{~kg} \mathrm{palm}^{-1}\right.$ month $\left.^{-1}\right)$ was significantly high compared to $2010(8.20 \pm 0.23$ $\mathrm{kg} \mathrm{palm}^{-1}$ month $\left.^{-1}\right)$ and $2009\left(9.37 \pm 0.23 \mathrm{~kg} \mathrm{palm}^{-1}\right.$ month $^{-1}$ ), and the difference between 2009 and 2010 was also significant. Irrespective of the year, TDMR of palms was highest during November to February and the values were significantly high compared to the other months, except October. TDMR was significantly low in June compared to those in September to March. The difference in TDMR during April to August was not significant. There was a highly significant negative correlation between TDMR of a palm in a given month and the number of set fruits in the inflorescence 'opened' in the same month $\left(\mathrm{p}<0.0001, \mathrm{R}^{2}=0.42\right)$ (Figure $\left.5 \mathrm{~b}\right)$.

\section{Response of pollen germination to temperature}

The percentage pollen germination (\% PG) was low at $20{ }^{\circ} \mathrm{C}$ and increased with increasing temperature

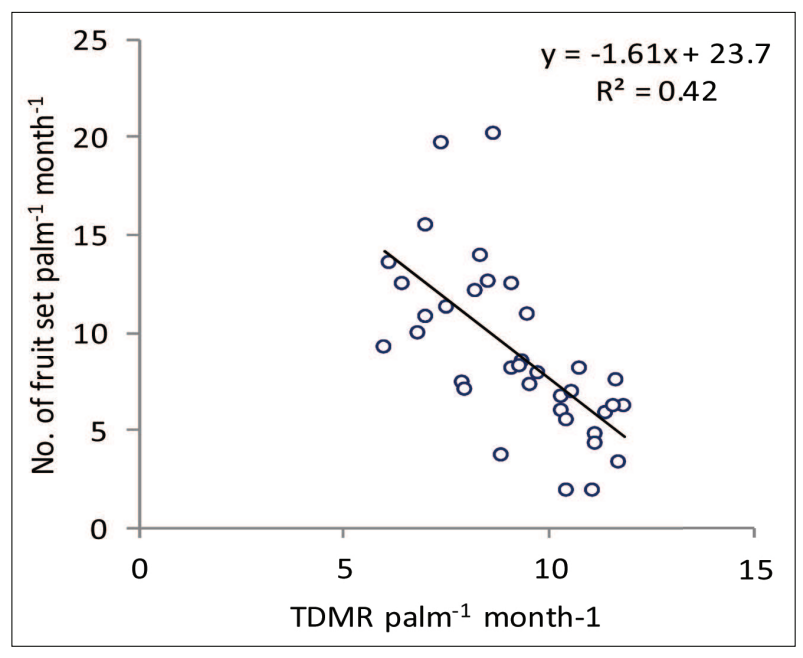

Figure 5b: Relationship between monthly total reproductive dry matter requirement (TDMR) of a palm in a given month and fruit set (FS) of the inflorescence opened in the same month 


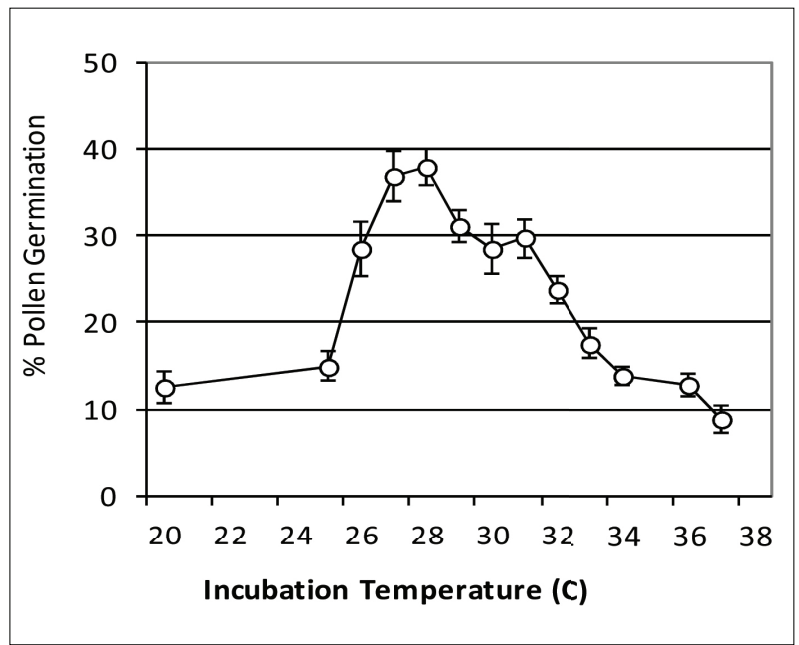

Figure 6: Response of percentage pollen germination to temperature

up to $28-29{ }^{\circ} \mathrm{C}$ and thereafter declined to about $9 \%$ at $37{ }^{\circ} \mathrm{C}$ (Figure 6). The maximum \% PG recorded at the optimum temperature was $38 \%$ (the constants for equation 1 were $a=35.00, b_{1}=0.11$ and $b_{2}=-3.10$ and $\left.\mathrm{R}^{2}=0.74\right)$. The optimum $\left(\mathrm{T}_{\text {opt-in vitro }}\right)$ and the maximum $\left(\mathrm{T}_{\text {max-in vitro }}\right)$ temperatures for in vitro pollen germination were $28^{\circ} \mathrm{C}$ and $39.7^{\circ} \mathrm{C}$, respectively. The $\%$ PG reduced to less than $20 \%$, or by more than half of the maximum $\%$ PG at temperatures higher than $33{ }^{\circ} \mathrm{C}$.

\section{Relationship between fruit setting and climatic parameters during early months after flowering}

The monthly variations in climatic factors are shown in Figures 1a and 1b. Despite significant variations observed in monthly rainfall, climatic water balance and solar radiation intensity during the critical period for fruit set, monthly fruit setting did not show significant correlations with any of these. However, the number of set fruits palm ${ }^{-1}$ month $^{-1}$ negatively correlated with the number of days with $\mathrm{T}_{\max }$ (day maximum) higher than $33{ }^{\circ} \mathrm{C}$ during the first three months of inflorescence opening $\left(p<0.001, R^{2}=0.18\right)$ (Figures $\left.7 a, 7 b\right)$.

\section{Relationship between final fruit yield and number of set fruits}

It was observed that the fluctuations in the harvested fruit number palm ${ }^{-1}$ month $^{-1}$ were strongly and positively correlated to the fluctuations in fruit set at three month stage. There was a very strong correlation $\left(\mathrm{R}^{2}=0.73\right)$ between the number of set fruits palm ${ }^{-1}$ month $^{-1}$ at three months stage and the harvested fruit number palm ${ }^{-1}$ month $^{-1}$ of the corresponding inflorescences on the $11^{\text {th }}$ month (Figure 8).

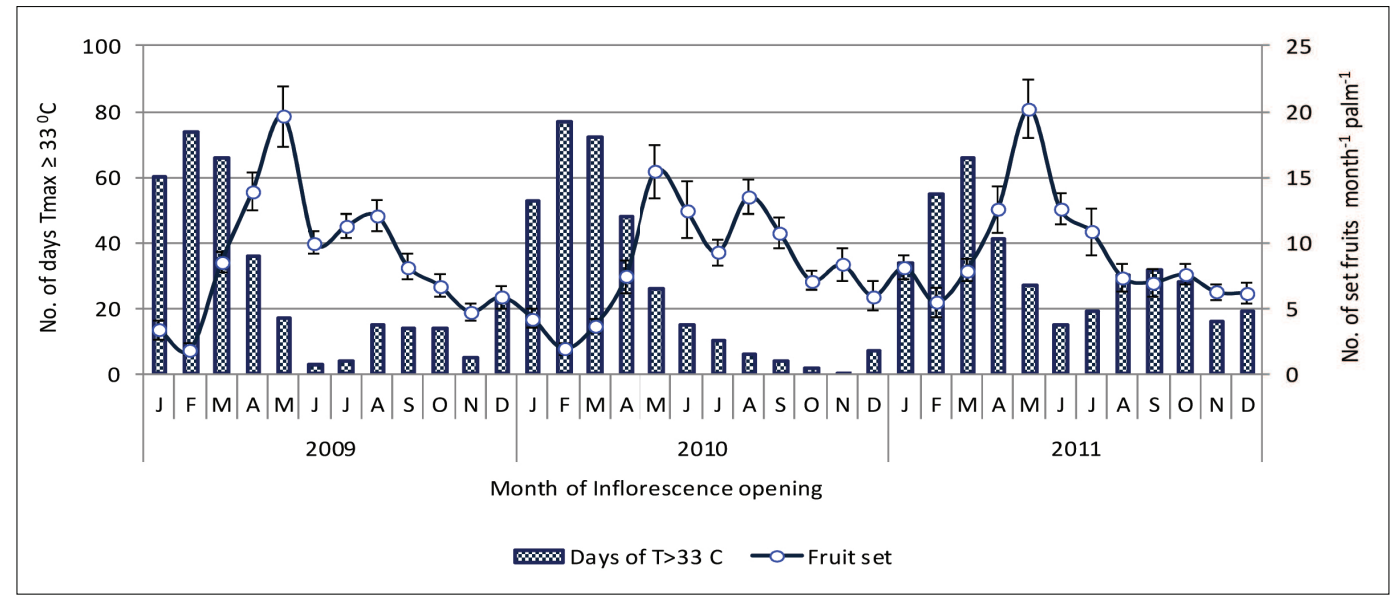

Figure 7a: Variation in fruit set (FS) of inflorescences opened from January 2009 through December 2011 and number of days that each inflorescence exposed to $\mathrm{T}_{\text {max }}$ greater than $33{ }^{\circ} \mathrm{C}$ during first three months of inflorescence opening 


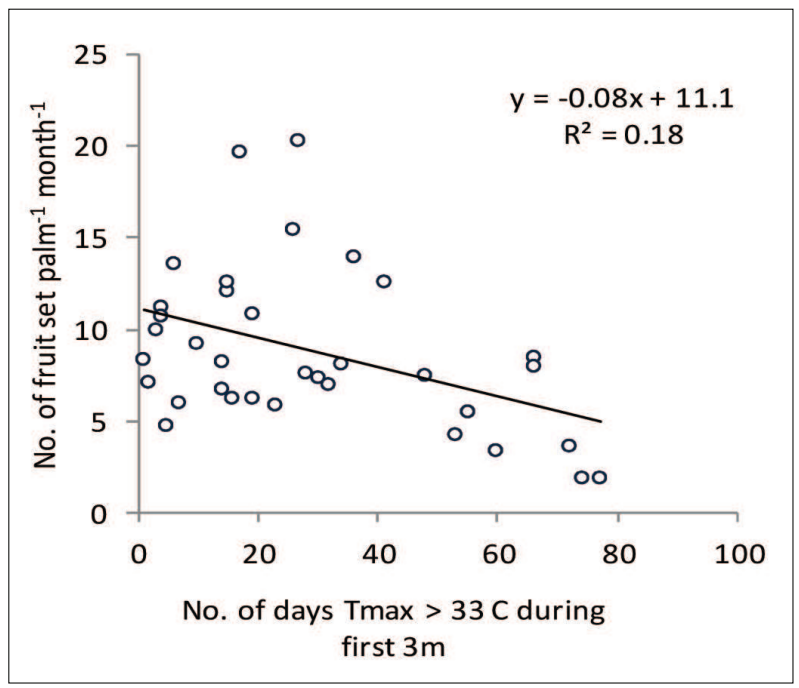

Figure 7b: Relationship between fruit set (FS) of inflorescences and number of days that inflorescence exposed to $\mathrm{T}_{\text {max }}$ greater than $33^{\circ} \mathrm{C}$ during first three months

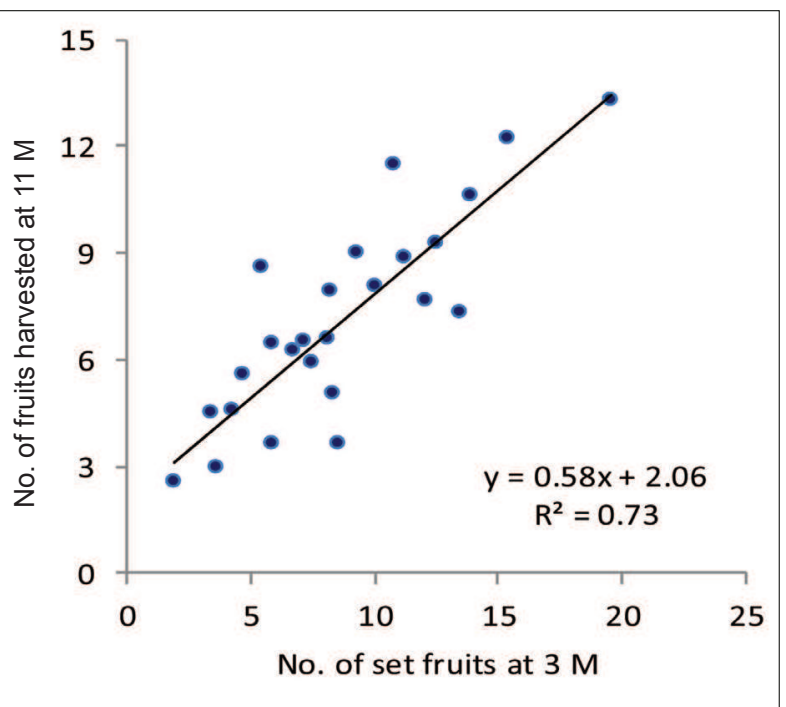

Figure 8: Relationship between fruit set palm ${ }^{-1}$ month $^{-1}$ (at three months stage, $3 \mathrm{M}$ ) and harvested fruit number palm ${ }^{-1}$ month $^{-1}$ of the corresponding inflorescences at maturity $(11 \mathrm{M})$

\section{DISCUSSION}

The study identified the main factors controlling fruit set and yield fluctuation in coconut. It revealed a cyclic pattern in fruit set over time. The fruit set of an inflorescence opened in a given month was strongly influenced by the total dry matter requirement of reproductive organs of the palm (TDMR) in the month of inflorescence opening (first month), and the number of heat stressed days $\left(\geq 33^{\circ} \mathrm{C}\right)$ during the first three months of inflorescence opening in addition to the initial number of female flowers (FF) produced in the inflorescence.

No previous studies have been reported on the quantitative information on fruit set of coconut and reproductive sink strength (TDMR of reproductive organs of developing fruits on the palm). In the present study, fluctuations in fruit set were in anti-phase with the fluctuations in TDMR. For instance, the fruit set was maximal in the inflorescences opened in May-June period where the TDMR was minimal and vice vers , indicating that competition between fruits at the time of pollination is a critical factor in determining fruit survival. Sink strength and source: sink ratios have been used to explain the cyclical fluctuations observed in fruit set and also the differences between varieties (Wubs et al., 2009a). Navarro et al. (2008) showed that fruit development is the driving force of yield variation in coconut, and the fruit production (number palm ${ }^{-1}$ month $^{-1}$ ) is poorly linked to photosynthetic rate. In Capsicum cultivars, source strength did not contribute to the differences in fruit set between varieties and it was the total sink strength that was negatively correlated to fruit set (Wubs et al., 2009a). In the present study, fruit set could not be explained by the rate of photosynthesis (measured every month) or assimilate availability for growth determined using leaf area index, solar radiation intensity and light extinction coefficient of coconut; hence a source limitation on fruit set is unlikely.

One of the limitations of the present study was the assumption of a constant growth respiration coefficient $(\alpha)$ for all the developmental stages of a coconut fruit in calculating the dry matter requirement for growth respiration. The reason for this assumption was the unavailability of published data on the growth or maintenance respiration coefficients for different development stages of fruits in coconut or oil palm, which is biologically and structurally similar to coconut. It has been reported that the growth respiration coefficient can be estimated on the basis of the biochemical composition of the end product in terms of structural carbohydrates, proteins, lipids (including oils and fats), lignin, organic acids and minerals, and transportation costs (Penning de Vries et al., 1983). The fruit of coconut consists of four main components, namely, the husk, shell, liquid endosperm (nut water) and solid endosperm (kernel including lipids). Growth during the post-pollination phase, that is, from fertilisation to maturity $(10-11$ month period) is mainly by cell enlargement which, is associated with the accumulation of food reserves 
(Jayasuriya \& Perera, 1985). Development of the fruit shows an approximate sigmoidal pattern with a substantial linear phase during which most of the increase in dry matter occurs. A linear phase is evident in the growth curves of each of the fruit components. The rapid growth phase of the husk, shell and kernel extends from 3-7 months, 5-9 months and 6-10 months, respectively. During this linear growth phase the average growth rate of solid kernel (with fats) was $39.9 \mathrm{~g} \mathrm{month}^{-1}$ and the highest rate of growth was $53.1 \mathrm{~g} \mathrm{month}^{-1}$ in the $9^{\text {th }}$ month after fertilisation (Jayasuriya \& Perera, 1985). Thus, the actual growth respiration coefficients would be greater in the 6-9 month period of bunch development due to higher energy requirement for lipid formation (Squire, 1984). Moreover, this assumption may have lead to the over-estimation of dry matter requirement for growth respiration in young fruits ( $1-6$ month period). However, since the present study was not focused on determining the growth respiration coefficients varying with the developmental stage of the fruit, coefficient values reported by Navarro et al. (2008) for a mature coconut fruit were used to estimate the dry matter requirement for growth respiration of developing fruits. Therefore, further research is needed to estimate the variation in growth respiration coefficient for different developmental stages of coconut fruit.

The impact of temperature is a complex function of intensity, duration and rate of temperature change (Wahid et al., 2007). In the present study, coconut inflorescences opened in January-February experienced an extensive heat stress period of about $50-74$ days during the first three months after opening in 2009 and 2010, and showed a very low fruit set of about $1-4$ nuts palm ${ }^{-1}$, whereas in 2011 the number of days with temperatures $>33^{\circ} \mathrm{C}$ during the same period was lower and, consequently, the fruit set was higher $(5-8$ nuts $)$. At the same time, the inflorescences opened during the last six months of 2009 and 2010 was exposed to less than 15 heat stressed days during the first three months whilst in 2011, the heat stressed days during the same period were much higher, resulting in a sharp reduction in fruit setting after May 2011 compared to the gradual reduction observed in the other two years. This reduction in fruit set can be attributed to the reduced pollen germination under heat stress (Reddy \& Kakani, 2007; Das et al., 2014). In the present study, pollen germination percentage ( $\%$ PG) was maximum $(38 \%)$ at $28{ }^{\circ} \mathrm{C}\left(\mathrm{T}_{\text {opt- in vitro }}\right)$, and it reduced by more than $50 \%$ of the maximum PG at temperatures higher than $33{ }^{\circ} \mathrm{C}$. Pollen did not germinate at temperatures higher than $39.5^{\circ} \mathrm{C}\left(\mathrm{T}_{\text {max-invitro }}\right)$. The maximum pollen germination (in vitro) observed at optimum temperature (38\%) was in agreement with the values obtained for coconut $(40 \%$,
Armendariz et al., 2006) and comparable to the values obtained for cotton (44\%, Kakani et al., 2005) and sorghum (52\%, Djanaguiraman et al., 2014). In addition, high temperature stress can have different effects on the development of male and female reproductive structures before inflorescence opening. Previous studies have suggested that when high temperature stress was imposed separately upon male and female gametes prior to pollination, pollen was often the most vulnerable (Zinn et al., 2010). For instance, in tomato, the reduction in fruit set under moderate heat stress was mostly due to a reduction in pollen quality and germination and this was mainly attributed to the disruption of sugar metabolism and proline translocation during the male reproductive development (pollen formation) a few days before anthesis (Sato et al., 2006). Heat stress can reduce carbohydrate deposition in pollen grains (Zinn et al., 2010). In wheat, heat stress during the period of microspore meiosis induced tapetum degradation. This degradation of nutritive tissues of the tapetum leads to pollen sterility. In addition, high temperatures can cause poor anther dehiscence characterised by tight closure of locules, which was shown to reduce pollen dispersal in rice and tomato and it can shorten the receptive period of stigma in female flowers, and thereby decrease the chances for successful pollination (Hedhly et al., 2005). In the development cycle of coconut inflorescence, sex determination, the formation of pollen and ovule mother cells and formation of pollen and ovule by meiosis take place four months, two months and three to four weeks before inflorescence opening, respectively (Perera et al., 2010). Therefore, further studies are being carried out to investigate the effects of climatic factors on the fertility of male and female reproductive organs and its relation to fruit set in coconut.

Female flower production determines the 'maximum potential' for the number of set fruits and the yield of an inflorescence. In the present study, female flower production was highest during summer (May) and there was a positive correlation between the variation in fruit set and variations in female flower production, although the ultimate fruit set was determined by the interactions among other factors as described earlier. Navarro et al. (2008) also attributed the seasonal variations in fruit set and yield to the fluctuations in female flower production in coconut cultivated under near optimum climatic and soil conditions in Vanuatu. In the same study, female flower production and consequently the fruit set were higher during warmer months compared to the cooler and drier months. Kasturi Bai et al. (2003) also showed a higher number of female flowers produced in coconut during summer (February to May) and monsoon (June 
to September) compared to the post monsoon period. However, in the present study, although the female flower production was generally higher during May - August period compared to the other months, it could not be explained by the correlations with climatic factors such as rainfall, solar radiation intensity or temperature. Further, this study revealed that the overriding effect on the highest fruit set in May was the higher production of female flowers in the same month.

This study adds a new dimension to the knowledge on fruit set and abortion in coconut and therefore, can be used to develop weather-driven process-based yield prediction models as has been proposed by Legros et al. (2009) for oil palm, a palm which is biologically and structurally close to coconut. Furthermore, the study revealed detrimental effects of high temperature on the pollination and fruit set of coconut. This sensitivity of fruit set to high temperature may differ among coconut varieties. Thus, the early fruit set under heat and drought stress can be used as a technique to screen coconut varieties for adaptation to a changing climate.

\section{CONCLUSION}

The fruit setting and abortion rates of an inflorescence during the first three months after inflorescence opening is a predominant factor controlling coconut yield fluctuation. Female flower production of a month (FF), total dry matter requirement of reproductive organs of a palm (TDMR) in the same month, and the number of heat stressed days $\left(\geq 33^{\circ} \mathrm{C}\right)$ during the first three months after inflorescence opening were the main factors controlling monthly variation in fruit set. There was a significant correlation between the fluctuation pattern of monthly fruit set (number) palm ${ }^{-1}$ and the respective final fruit yield palm ${ }^{-1}$. There was a lag period of 11 months between fruit set (opening of female flowers) and final harvest.

\section{Acknowledgement}

Authors extend their sincere thanks to the staff of the Plant Physiology Division, Coconut Research Institute, Sri Lanka for their support in field data collection.

\section{REFERENCES}

1. Allen R.C., Pereira I.S., Raes D. \& Smith M. (1998). Crop evapotranspiration - guidelines for computing crop water requirements. FAO Irrigation and Drainage Paper No. 56. Food and Agriculture Organization of the United Nations, Rome, Italy.
2. Armendariz B.H.C., Oropeza C., Chan J.L., Maust B., Aguilar C.C.C. \& Saenz L. (2006). Pollen fertility and female flower anatomy of micropropagated coconut palms. Revista Fitotecnia Mexicana 29(4): 373 - 378.

3. Burke J.J., Velten J. \& Oliver M.J. (2004). In vitro analysis of cotton pollen germination. Agronomy Journal 96: $359-368$.

DOI: http://dx.doi.org/10.2134/agronj2004.0359

4. Das S., Krishnan P., Nayak M. \& Ramakrishnan B. (2014). High temperature stress effects on pollens of rice (Oryza sativa L.) genoypes. Environmental and Experimental Botany 101: 36 - 46.

DOI: http://dx.doi.org/10.1016/j.envexpbot.2014.01.004

5. Djanaguiraman M., Vara Prasad P.V., Murugan M., Perumal R. \& Reddy U.K. (2014). Physiological differences among sorghum (Sorghum bicolor L. Moench) genotypes under high temperature stress. Environmental and Experimental Botany 100: 43 - 54.

DOI: http://dx.doi.org/10.1016/j.envexpbot.2013.11.013

6. Hedhly A., Hormaza J.I. \& Herrero M. (2005). The effect of temperature on pollen germination, pollen tube growth and stigmatic receptivity in peach. Plant Biology 7: $476-483$. DOI: http://dx.doi.org/10.1055/s-2005-865850

7. Henson I.E. (2007). Modeling oil palm yield based on source and sink. Oil Palm Bulletin 54: 27 - 51.

8. Jayasuriya V.U.De.S. \& Perera R.K.I.S. (1985). Growth, development and dry matter accumulation in the fruit of Cocos nucifera L. var. nana form pumila. Cocos 3: $16-21$.

9. Kakani V.G., Prasad P.V.V., Craufurd P.Q. \& Wheeler T.R. (2002). Response of in vitro pollen germination and pollen tube growth of groundnut (Arachis hypogaea L.) genotypes to temperature. Plant, Cell and Environment 25: $1651-1661$.

DOI: http://dx.doi.org/10.1046/j.1365-3040.2002.00943.x

10. Kakani V.G., Reddy K.R., Koti S., Wallace T.P., Prasad P.V.V., Reddy V.R. \& Zhao D. (2005). Difference in in vitro pollen germination and pollen tube growth of cotton cultivars in response to high temperature. Annals of Botany 96: $59-67$.

DOI: http://dx.doi.org/10.1093/aob/mci149

11. Kasturi Bai K.V., Reddy S.D.V., Ratnambal M.J. \& Laxman R.H. (2003). Factors contributing to female flower production and button shedding in coconut. Journal of Plantation Crops 31(2): $33-36$.

12. Legros S., Mialet-Serra I., Caliman J.P., Siregar F.A., Clement-Vidal A. \& Dingkuhn M. (2009). Phenology and growth adjustments of oil palm (Elaeis guineensis) to photoperiod and climate variability. Annals of Botany 104: $1171-1182$.

DOI: http://dx.doi.org/10.1093/aob/mcp214

13. Liyanage D.V. (1950). Sex life of the coconut palm. Ceylon Coconut Quarterly 11(2): 33 - 35.

14. Mialet-Serra I., Clement-Vidal A., Roupsard O., Jourdan C. \& Dingkuhn M. (2008). Whole-plant adjustments in coconut (Cocos nucifera) in response to sink-source imbalance. Tree Physiology 28: 1199 - 1209. 
DOI: http://dx.doi.org/10.1093/treephys/28.8.1199

15. Nainanayake N.P.A.D., Ranasinghe C.S. \& Tennakoon A.T. (2008). Effect of drip irrigation on canopy and soil temperature, leaf gas exchange, flowering and nut setting of mature coconut (Cocos nucifera L.). Journal of the National Science Foundation of Sri Lanka 36(1): 47 - 54. DOI: http://dx.doi.org/10.4038/jnsfsr.v36i1.131

16. Navarro M. et al. (14 authors) (2008). Fruit development, not GPP, drives seasonal variation in NPP in a tropical palm plantation. Tree Physiology 28: 1661 - 1674.

DOI: http://dx.doi.org/10.1093/treephys/28.11.1661

17. Peiris T.S.G., Hansen J.W. \& Zubair L. (2008). Use of seasonal climate information to predict coconut production in Sri Lanka. International Journal of Climatology 28: $103-110$.

DOI: http://dx.doi.org/10.1002/joc.1517

18. Peiris T.S.G. \& Thattil R.O. (1997). Assessment of the effects of environmental factors on yield of coconut (Cocos nucifera L.). Cocos 12: $1-17$.

19. Peiris T.S.G., Thattil R.O. \& Mahindapala R. (1995). An analysis of the effect of climate and weather on coconut (Cocos nucifera). Experimental Agriculture 31: $451-460$.

DOI: http://dx.doi.org/10.1017/S0014479700026430

20. Penning de Vries F.W.T., van Laar H.H. \& Chardon M.C.M. (1983). Bioenergetics of growth of seeds, fruits and storage organs. Potential Productivity of Field Crops Under Different Environments. International Rice Research Institute, Manila, The Philippines.

21. Perera P.I.P., Hocher V., Weerakoon L.K., Yakandawala D.M.D., Fernando S.C. \& Verdeil J.L. (2010). Early inflorescence and floral development in Cocos nucifera L. (Arecaceae: Arecoideae). South African Journal of Botany 76: $482-492$.

DOI: http://dx.doi.org/10.1016/j.sajb.2010.03.006

22. Ranasinghe C.S. (2008). Report of the Plant Physiology Division. Annual Report of the Coconut Research Institute (eds. C. Jayasekara ), pp. 198 - 207. Coconut Research Institute, Bandirippuwa Estate, Lunuwila.

23. Ranasinghe C.S., Waidyarathna K.P., Pradeep I.A.P.C. \& Meneripitiya M.S.K. (2010). Approach to screen coconut varieties for high temperature tolerance by in-vitro pollen germination. Cocos 19(1): $1-12$.

24. Ranasinghe C.S., Illankoon I.M.I., Silva L.R.S., Premasiri R.D.N. \& Pradeep A.P.C. (2011). Transitory carbohydrate reserves in vegetative organs of coconut under different growth conditions and its relation with reproductive and vegetative growth of the palm. Cocos 19: 77 - 91.

25. Ranasinghe C.S. \& Thimothias K.S.H. (2012). Estimation of carbon sequestration potential in coconut plantations under different growth conditions. Journal of the National Science Foundation of Sri lanka 40(1): 77 - 93.

26. Ranasinghe C.S., Premasiri R.D.N. \& Pradeep A.P.C. (2014). Vulnerability of coconut based agroforestry system in Sri Lanka to climate change. Abstracts of the $3^{\text {rd }}$ World Congress on Agroforestry: Trees for life: Accelerating the Impact of Agroforestry (eds. M.A. Wachira, B. Rabar \& C.
Magaju). 10 - 14 February, New Delhi, India, p. 287.

27. Reddy K.R. \& Kakani V.G. (2007). Screening Capsicum species of different origin for high temperature tolerance by in vitro pollen germination and pollen tube length. Scientia Horticulturae 112: 130 - 135.

DOI: http://dx.doi.org/10.1016/j.scienta.2006.12.014

28. Sato S., Kamiyama M., Iwata T., Makita N., Furukawa H. \& Ikeda H. (2006). Moderate increase of mean daily temperature adversely affects fruit set of Lycopersicon esculentum Mill by disrupting specific physiological processes in male reproductive development. Annals of Botany 97(5): 731 - 738.

DOI: http://dx.doi.org/10.1093/aob/mc1037

29. Somasiri L.L.W., Nadarajah N., Amarasiri L. \& Gunathilake H.A.G. (1994). Land Suitability Assessment of Coconut Growing Areas in the Coconut Triangle (eds. C.R Panabokke \& R. Mahindapala). Coconut Research Institute of Sri Lanka, Bandirippuwa Estate, Lunuwila.

30. Squire G.R. (1984). Light interception, productivity and yield of oil palm. Occasional Report, p. 45. Palm Oil Research Institute of Malaysia, Selangor, Malaysia.

31. Thomas R.J., Nair R.V., Mathews C., Ajithkumar R., Sasikala M. \& Nampoothiri C.K. (2012). Studies on fruit set in coconut upon artificial pollination in various cross combinations. Indian Journal of Horticulture 69(1): $7-12$.

32. Vara Prasad P.V., Craufurd P.Q., Summerfield R.J. \& Wheeler T.R. (2000). Effects of short episodes of heat stress on flower production and fruit set of groundnut (Arachis hypogaea L.). Journal of Experimental Botany 51(345): $777-784$.

DOI: http://dx.doi.org/10.1093/jexbot/51.345.777

33. Wahid A., Gelani S., Ashraf M. \& Foolad M.R. (2007). Heat tolerance in plants: an overview. Environmental and Experimental Botany 61: 199 - 223.

DOI: http://dx.doi.org/10.1016/j.envexpbot.2007.05.011

34. Wubs A.M., Ma Y., Heuvelink E. \& Marcelis L.F.M. (2009a). Genetic differences in fruit set patterns are determined by differences in fruit sink strength and a source: sink threshold for fruit set. Annals of Botany 104: $957-964$.

DOI: http://dx.doi.org/10.1093/aob/mcp181

35. Wubs A.M., Heuvelink E. \& Marcelis L.F.M. (2009b). Abortion of reproductive organs in sweet pepper (Capsicum annum L.): a review. Journal of Horticultural Science and Biotechnology 84(5): $467-475$.

36. Wubs A.M., Heuvelink E., Marcelis L.F.M. \& Hemerik L. (2011). Quantifying abortion rates of reproductive organs and effects of contributing factors using time to event analysis. Functional Plant Biology 38: 431 - 440.

DOI: http://dx.doi.org/10.1071/FP10249

37. Zinn K.E., Tunc-Ozdemir M. \& Harper J.F. (2010). Temperature stress and plant sexual reproduction: uncovering the weakest links. Journal of Experimental Botany 61(7): 1959 - 1968.

DOI: http://dx.doi.org/10.1093/jxb/erq053 